\title{
INFLUENCE OF TWO-HOUR TOURNIQUETS ISCHEMIA OF LIMB AND ACUTE BLOOD LOSS ON SYSTEMIC DISORDERS OF THE BODY IN THE REPERFUSION PERIOD (EXPERIMENTAL STUDY)
}

DOI: $10.36740 /$ WLek202007104

\author{
Ivanna I. Horban, Arsen A. Hudyma, Roman V. Maksymiv, Iryna V. Antonyshyn \\ I. HORBACHEVSKY TERNOPIL NATIONAL MEDICAL UNIVERSITY, MINISTRY OF HEALTH OF UKRAINE, TERNOPIL, UKRAINE
}

\begin{abstract}
The aim: to find out the effect of a two-hour tourniquets ischemia of the limb and acute blood loss on systemic disorders of the body in the postperfusion period. Materials and methods: The experiments were performed on 96 nonlinear male rats weighing 200-220 g. All experiments were performed under sodium thiopental anesthesia. In the first experimental group, two-hour tourniquets limb ischemia was simulated. In the second experimental group, acute blood loss was modeled. In the third experimental group, these lesions were combined. In 1 and 2 hours, as well as in 1, 7 and 14 days, the biliary function of the liver was determined in the experimental animals. Results: Two-hour tourniquets ischemia of the limb in the reperfusion period compared with the control was accompanied by a significant decrease in the rate of bile excretion, which reached a minimum value in $3 \mathrm{~h}-1$ day of the experiment and returned to the control level in 14 days. After the simulation of acute blood loss, the rate disturbance of bile excretion became significantly greater in all observation periods. The complication of acute ischemia-limb reperfusion caused a greater decrease in the rate of bile excretion with a maximum in 1 day of the experiment. Under these conditions, at 1, 7, and 14 days, the indicator was statistically significantly lower than in the other study groups. Conclusions: In the case of acute blood loss, complicated by two-hour tourniquets ischemia of the limb, the reperfusion period is accompanied by a summation of the negative impact of blood loss, ischemia and reperfusion of the limb on the functional state of the liver, which is a significant decrease in the rate of bile excretion with a maximum in 1 day, which further increases, but up to 14 days does not reach the level of control.
\end{abstract}

KEY WORDS: blood loss, tourniquets, ischemia, reperfusion, bile excretion

Wiad Lek. 2020;73(7):1330-1333

\section{INTRODUCTION}

Today one of the current problems is the increasing incidence of terrorist attacks and local armed conflicts, which has an impact on public health, [1]. Under these circumstances, the main reason of the death of victims and injured is acute blood loss [2]. An effective tool to stop massive external limb bleeding is considered to be a tourniquet that completely stops arterial blood flow for a safe period of up to two hours [3].

It is established that two hours of full bleeding stop in the limb causes damage to the nerves and vessels under the tourniquet, which leads to myonecrosis, rhabdomyolysis, deep vein thrombosis [4]. Some authors have shown that even greater disturbances in soft tissues of the limb occur after its reperfusion [5]. The processes of lipid peroxidation are significantly activated, the destruction of cell membranes is increased in muscle tissue, which causes inflammation of ischemia-induced local areas. The question of the influence of inflammatory mediators and toxic metabolites which enter the systemic circulation from the ischemic limb on vital organs remains debatable.

\section{THE AIM}

To find out the effect of two-hour tourniquets ischemia of the limb and acute blood loss on systemic disorders of the body in the reperfusion period (due to model of liver biliary function).

\section{MATERIALS AND METHODS}

The experiments were performed on 96 non-linear male rats weighing 200-220 g according to the rules of the "European Convention for the Protection of Vertebrate Animals, Used for Experimental and Other Scientific Purposes" (European Convention, 1984). Bioethics Commission of I. Horbachevsky Ternopil National Medical University Ministry of Health of Ukraine found conducted experiments to be in compliance with the basic ethical standards of work with laboratory animals (No. 54 dated 27.08.2019).

All animals were divided into five groups: one control and four experimental (6 rats in each group). The first experimental group included animals that modeled ischemia-reperfusion of the limb. Under sodium thiopental anesthesia (40 mh•kh- ${ }^{1}$ of animal weight) animals were put proximally superimposed elastic strip tourniquet "SWAT-T" (USA) on the left leg, width of it is $10 \mathrm{~mm}$, duration up to 120 minutes. The tourniquet was tightened according to the effective pressure indicator on it which stops the blood flow. The anemia of the limb was further confirmed by the rheographic method. In the second ex- 
Table I. Dynamics of biliary velocity (ml•H-1•kg-1) after acute blood loss complicated by ischemia-reperfusion of the limb (Me (LQ; UQ)) - median (lower and upper quartile)

\begin{tabular}{|c|c|c|c|c|c|}
\hline \multirow{2}{*}{ Experimental group } & \multicolumn{5}{|c|}{ Reperfusion period } \\
\hline & $2 \mathrm{~h}$ & $3 \mathbf{h}$ & 1 day & 7 day & 14 day \\
\hline \multicolumn{6}{|c|}{ Control $=2.25(2.19 ; 2.32)(n=6)$} \\
\hline $\begin{array}{l}\text { The first experimental group } \\
\text { Ischemia-reperfusion }\end{array}$ & $\begin{array}{c}2.15 \\
(2.06 ; 2.19) \\
(n=6)\end{array}$ & $\begin{array}{c}1.74^{* 2 h} \\
(1.72 ; 1.76) \\
(n=6)\end{array}$ & $\begin{array}{c}1.83^{* 2 h} \\
(1.81 ; 1.93) \\
(n=6)\end{array}$ & $\begin{array}{c}2.09^{* 3 h, 1 d} \\
(2.06 ; 2.16) \\
(n=6)\end{array}$ & $\begin{array}{c}2.32^{2 \mathrm{~h}, 3 \mathrm{~h}, 1 \mathrm{~d}, 7 \mathrm{~d}} \\
(2.24 ; 2.47) \\
(\mathrm{n}=6)\end{array}$ \\
\hline $\begin{array}{l}\text { The second experimental group } \\
\text { Blood loss }\end{array}$ & $\begin{array}{c}1.98^{*} \\
(1.85 ; 2.07) \\
(n=6)\end{array}$ & $\begin{array}{c}2.45^{* 2 h} \\
(2.34 ; 2.56) \\
(n=6)\end{array}$ & $\begin{array}{c}1.58^{* 2 h, 3 h} \\
(1.46 ; 1.64) \\
(n=6)\end{array}$ & $\begin{array}{c}1.83^{* 3 h, 1 d} \\
(1.74 ; 1.93) \\
(n=6)\end{array}$ & $\begin{array}{c}1.95^{*} 3 \mathrm{~h}, 1 \mathrm{~d} \\
(1.90 ; 2.03) \\
(n=6)\end{array}$ \\
\hline $\begin{array}{l}\text { The third experimental group } \\
\text { Ischemia-reperfusion + Blood loss }\end{array}$ & $\begin{array}{c}1.84^{*} \\
(1.82 ; 1.96) \\
(n=6)\end{array}$ & $\begin{array}{c}1.72^{*} \\
(1.67 ; 1.83) \\
(n=6)\end{array}$ & $\begin{array}{c}1.29^{* 2 \mathrm{~h}, 3 \mathrm{~h}} \\
(1.19 ; 1.38) \\
(\mathrm{n}=6)\end{array}$ & $\begin{array}{c}1.58^{* 2 h, 1 d} \\
(1.50 ; 1.69) \\
(n=6)\end{array}$ & $\begin{array}{c}1.63^{* 2 \mathrm{~h}, 1 \mathrm{~d}} \\
(1.56 ; 1.77) \\
(\mathrm{n}=6)\end{array}$ \\
\hline$p_{1-2}$ & $>0.05$ & $<0.05$ & $<0.05$ & $<0.05$ & $<0.05$ \\
\hline $\mathrm{p}_{1-3}$ & $<0.05$ & $>0.05$ & $<0.05$ & $<0.05$ & $<0.05$ \\
\hline $\mathrm{p}_{2-3}$ & $>0.05$ & $<0.05$ & $<0.05$ & $<0.05$ & $<0.05$ \\
\hline
\end{tabular}

Notes:

1. * - differences in control group are statistically probable $(p<0.05)$;

2. $p_{1-2}$ - probable differences between the experimental groups 1 and 2 ;

3. $p_{1-3}$ - probable differences between the experimental groups 1 and 2 ;

4. $p_{2-3}$ - probable differences between experimental groups 1 and 3;

$5 .{ }^{3 h, 4 h, 1 d, 7 d}$ - differences due to third and fourth $h$, respectively, as well as on 1 and 7 day of the experiment are statistically probable $(p<0.05)$.

perimental group under conditions of sodium thiopental anesthesia, acute blood loss was simulated by incision of the femoral vein. After substantiation of blood volume loss up to $20 \%$ of circulating blood volume, the animals were provided with hemostasis. In the third experimental group, these injuries were combined.

In the control group, the animals were anesthetized using an equivalent dose of sodium thiopental, a tourniquet was applied for $2 \mathrm{~h}$ without stopping the blood flow, and subsequently taken for studies in $1 \mathrm{~h}$.

In 1 and 2 hours, as well as in 1, 7 and 14 days functional state of the liver was determined in experimental animals. The biliary function of the liver was studied in each experimental group by catheterization of the common bile duct and bile intake during $1 \mathrm{~h}$ under conditions of sodium thiopental anesthesia $(60 \mathrm{mg}$ $\mathrm{kg}^{-1}$ mass) [6]. The rate of bile excretion was calculated based on the hour and kilogram of animal's body weight. After bile collection, rats were taken out from the experiment by total bloodletting from the heart, which in the early period of the experiment corresponded to 2 and $3 \mathrm{~h}$ of reperfusion.

The estimation of probable differences between the experimental groups was performed using the non-parametric Mann-Whitney criterion.

\section{RESULTS}

Studies have shown (Table I) that in experimental group 1 , in which the ischemia-reperfusion of the limb was simulated, in $1 \mathrm{~h}$ of reperfusion, the rate of bile excretion did not change significantly compared to the control group. However, in $3 \mathrm{~h}$ of the reperfusion period, the index de- creased by $22.7 \%$ compared to the control $(\mathrm{p}<0.05)$ and by $19.1 \%$ compared to $2 \mathrm{~h}$ of observation $(\mathrm{p}<0.05)$ and remained at the same level up to 1 day of experiment. In 7 days, the rate of bile excretion increased and was statistically significantly higher than in the previous observation period $(p<0.05)$, but remained significantly lower than in the control $(p<0.05)$. In 14 days, the index increased further and reached the level of the control group $(\mathrm{p}<0.05)$.

In the case of acute blood loss (experimental group 2), the rate of bile excretion was significantly lower than in the control in $2 \mathrm{~h}$ of reperfusion (by $12.0 \%, \mathrm{p}<0.05$ ). In 3 hours, the indicator became even smaller: by $32.9 \%$ compared to the control $(\mathrm{p}<0.05)$ and by $23.3 \%$ compared to the previous observation period ( $\mathrm{p}<0.05)$. In 1 day, the rate of bile excretion remained at the level of $3 \mathrm{~h}(\mathrm{p}<0,05)$ and was $29.8 \%$ lower than in the control. In the future, the indicator increased, but by the 14 th day it did not reach the level of control and was $13.3 \%$ lower $(\mathrm{p}<0.05)$.

In the case of combination of acute blood loss with limb ischemia-reperfusion (experimental group 3), the rate of bile excretion in $2 \mathrm{~h}$ was $18.2 \%$ lower than in the control $(\mathrm{p}<0.05)$. In $3 \mathrm{~h}$ of the conducting experiment, the index decreased even more - by $20.6 \%$ compared to the previous observation period $(\mathrm{p}<0.05)$ and by $35.1 \%$ - compared to the control $(\mathrm{p}<0.05)$. In 1 day the indicator reached the minimum value. It decreased by $42.7 \%(\mathrm{p}<0.05)$ compared to the control and was statistically significantly smaller than in the previous observation periods $(\mathrm{p}<0.05)$. Further up to 7 days the indicator increased (by $22.5 \%$ compared to the previous observation period, $\mathrm{p}<0,05)$ and remained at the same level up to 14 days. 
Comparison of the experimental groups with each other showed that in $2 \mathrm{~h}$ of the experiment in the experimental group 3 the rate of bile excretion was significantly lower than in the experimental group 1 (by $14.4 \%, \mathrm{p}_{2-3}<0.05$ ). In $3 \mathrm{~h}$, the indicator was statistically significantly lower in experimental groups 2 and 3 compared to experimental group $1\left(13.2 \%, \mathrm{p}_{1-2}<0.05\right.$ and $16.1 \%, \mathrm{p}_{1-3}<0.05$, respectively). In 1, 7 and 14 days of the experiment, the indicator in experimental group 3 was statistically significantly lower than in experimental groups 1 and $2\left(\mathrm{p}_{1-3}<0,05, \mathrm{p}_{2-3}<0,05\right)$ and significantly lower in experimental group 2 compared with experimental group $1\left(\mathrm{p}_{1-2}<0.05\right)$.

\section{DISCUSSION}

The obtained results indicate that in the case of reperfusion of the limb in two hours of ischemia, preconditions arise that adversely affect the functional state of the liver, which is manifested by a decrease in the rate of bile secretion with a minimum of $3 \mathrm{~h}$ and 1 day of experiment and normalization to 14 days. On the base of the pathogenesis of biliary tract disorders is a decrease in the formation of bile components, slowing of the excretion process in the biliary tract, swelling of the liver parenchyma with impaired bile flow, and impaired bile duct motility [7]. Given the membrane dependence of bile formation and excretion processes, it can be assumed that toxins from the ischemic limb entering the bloodstream will cause damage to cellular and subcellular membranes, primarily by enhancing the processes of lipid peroxidation, which, in turn, work separately [8]. Under these conditions, the source of systemic prooxidant action is muscles, vessels, and nerve fibers that have been ischemic for two hours and are subject to reperfusion damage [9].

In conditions of acute blood loss, bile ductility disorders were observed during all observation periods, which was higher than in experimental group 1. By 14 days the index did not reach the level of the control group. The decrease in bile excretion is obviously due to the development of hypovolemic shock, which is characterized by "centralization" of blood circulation and a decrease in the blood supply to the organs of the gastrointestinal tract [10].

In conditions of acute blood loss, complicated by twohour ischemia-reperfusion of the limb, the disorders were more pronounced. If in 2 and $3 \mathrm{~h}$ of experiment in this group the rate of bile excretion was at the level of animals with acute blood loss, then in the future the indicator became statistically significantly lower. It can be assumed that in experimental group 3 there is an over-placement of pathogenic mechanisms of limb ischemia-reperfusion and acute blood loss. Organ specificity of biliary function puts it in a number of important and informative criteria and allows to monitor the status of hepatocyte microsomes, where cholesterol synthesis of bile acids and conjugation of bilirubin with glucuronic acid occur; the state of cytoplasmic membranes of the sinusoidal pole of hepatocytes that capture bilirubin and cholesterol from the blood; the state of the hepatocytes biliary pole, where the compo- nents of bile are transferred to the primary bile capillary; the state of the bile ducts, which provide the outflow of bile into the duodenum [7]. In addition to, a number of publications investigating biliary liver function have been successfully used as a model of organ dysfunction and insufficiency [11].

The result we have obtained is of considerable practical importance, since in the course of assisting the victims and the injured with acute blood loss, it aims at obligatory consideration of the fact of ischemia and reperfusion of the limb, which can significantly deepen the course of hypovolemic shock and stimulate the development of organ dysfunction. All this requires finding effective means of eliminating the effects of limb ischemia-reperfusion in the case of acute blood loss.

\section{CONCLUSIONS}

1. Two-hour ischemia of the limb in the reperfusion period is accompanied by a significant decrease in the rate of bile excretion, which reaches a minimum value in 3 $\mathrm{h}-1$ day of the experiment and returns to the control level in 14 days.

2. After modeling of acute blood loss, the amplitude of bile duct velocity disorders in all observation periods becomes statistically significantly greater than in the case of ischemia-reperfusion, but their dynamics remains similar with a maximum decrease in $3 \mathrm{~h}-1$ day and an increase - in 14 days, which does not reach level of control.

3. The complication of acute blood loss of limb ischemia-reperfusion is accompanied by a summation of their negative effect on the functional state of the liver with a maximum in 1 day of the experiment. Under these conditions, in 1, 7 and 14 days, the rate of bile excretion is statistically significantly lower than in the experimental group in which the most acute blood loss was simulated.

\section{REFERENCES}

1. Global Terrorism Index. - Accessed: http://economicsandpeace.org/wpcontent/uploads/2015/11/2015-Global-Terrorism-Index-Report.pdf.

2. Elster E.A., Frank K.B., Todd E.R. Implications of Combat Casualty Care for Mass Casualty Events. JAMA. 2013;310(5):475-476.

3. Efficacy of Prehospital Application of Tourniquets and Hemostatic Dressings To Control Traumatic External Hemorrhage DOT HS 811 999b. Washington, DC: National Highway Traffic Safety Administration. 2014:2-3.

4. Clasper J.C., Brown K.V., Hill P. Limb complications following pre-hospital tourniquet use. J R Army Med Corps. 2009;155(3):200-202.

5. Televiak A. T. Dynamika pokaznykiv perekysnoho okyslennia lipidiv ta antyoksydantnoho zakhystu v m'iazovii tkanyni zadnikh kintsivok shchuriv pry rozvytku ishemichno-reperfuziinoho syndromu (eksperymentalne doslidzhennia) [Indicator dynamics of lipid peroxidation and antioxidant protection in rat muscular tissue of hind limbs in the development of ischemic-reperfusion syndrome (experimental study)]. Achievements of clinical and experimental medicine. 2018;3(35):132-139. (In Ukrainian). 
6. Drohovoz S.M., Hubskyi Yu.I., Skakun M.P., Kovalenko V.M., Derymedvid L.V. Eksperymentalne vyvchennia kholespazmolitychnoi, kholelitiaznoi ta hepatoprotektornoi aktyvnosti novykh likarskykh zasobiv [Experimental study of cholospasmolytic, cholelithiasis and hepatoprotective activity of new medicine]. In: Doklinichni doslidzhennia likarskykh zasobiv: metodychni rekomendatsii [Preclinical studies of drugs: methodical recommendations]; K.: Avicenna, 2001:334-351. (In Ukrainian).

7. Hudyma A.A., Yarema V.V. Porushennia zhovchoutvorennia i zhovchovydilennia v rannii period politravmy u tvaryn z riznoiu metabolizuvalnoiu zdatnistiu pechinky [Violation of bile formation and bile excretion in the early period of polytrauma in animals with different liver metabolizing capacity]. Achievements of clinical and experimental medicine. 2012;2:48-52. (In Ukrainian).

8. Kryliuk V.0., Kuzminskyi I.V., Hrodetskyi V.K. Vplyv ishemichnoreperfuziinoho syndromu na aktyvatsiiu systemy perekysnoho okysnennia lipidiv u tkanyni pechinky [Influence of ischemic-reperfusion syndrome on activation of lipid peroxidation system in liver tissue]. Clinical and experimental pathology. 2018;17(4):53-59. (In Ukrainian).

9. Telev'iakA.A.,VeresiukT.0., Selskyi P.R., Boimystruk I.I. Biokhimichnizminy u syrovattsi krovi shchuriv pry ishemichno-reperfuziinomu syndromi (eksperymentalne doslidzhennia) [Biochemical changes in serum of rats under ischemic-reperfusion syndrome (experimental study)]. Achievements of clinical and experimental medicine. 2018;2:122-128.

10. Roshchin H.H., KryliukV.O., Iskra N.I. Hostra krovovtrata pry travmatchynykh poshkodzhenniakh [Acute blood loss in the case of traumatic demages]. Acute and emergency states in doctor's practice. 2019. Accessed https:// urgent.com.ua/ua-issue-article-125. (In Ukrainian).

11. Kashchak T.V., Dzetsiukh T.I., Uhlyar U.V. The peculiarities of the functional state of the liver under conditions of skeletal trauma, thermal burns of the skin and their combinations in the period of later manifestations of traumatic disease in the experiment. Journal of Education, Health and Sport. 2019;9(8):644—654. D0I http://dx.doi. org/10.5281/zenodo.3406187
The article was made within the framework of a complex research topic of the Educational and Scientific Institute of Modeling and Analysis of Pathological Processes of the I. Horbachevsky Ternopil National Medical University of the Ministry of Health of Ukraine "Systemic and organ disorders due to the effects of extraordinary factors on the organism, mechanisms of their development and pathogenetic correction" (State Registration №. 016U003390).

\section{ORCID and contributionship:}

Ivanna I. Horban - 0000-0001-9406-5435 A,B,C,D

Arsen A. Hudyma - 0000-0002-1282-2728 A,E,F

Roman V. Maksymiv - 0000-0003-4726-8824 ${ }^{B, C}$

Iryna $V$. Antonyshyn - 0000-0002-1252-9177 ${ }^{A, D}$

\section{Conflict of interest:}

The Authors declare no conflict of interest.

\section{CORRESPONDING AUTHOR Arsen A. Hudyma \\ Horbachevsky Ternopil National Medical University \\ 1 Maidan Voli st., 46001 Ternopil, Ukraine \\ tel: +380964537862 \\ e-mail:arsgudyma@gmail.com}

Received: 10.03 .2020

Accepted: 19.06 .2020

A - Work concept and design, B - Data collection and analysis, C - Responsibility for statistical analysis, D-Writing the article, $\mathbf{E}$-Critical review, $\mathbf{F}$ - Final approval of the article 